\title{
THE DIALECTICAL PRESENTATION OF THE GENERAL NOTION OF CAPITAL IN THE LIGHT OF HEGEL'S PHILOSOPHY: ON THE LOGICAL ANALYSIS OF POLITICAL ECONOMY WITH SPECIAL CONSIDERATION OF ADORNO AND THE RESEARCH RESULTS OF RUBIN, BACKHAUS, REICHELT, UNO, AND SEKINE ${ }^{123}$
}

Ken Kubota ${ }^{4}$

\begin{abstract}
:
Hegel and Marx share the concept of a strict deduction of the genesis of forms - forms of thought and being in the case of Hegel, and economic forms in the case of Marx: "the form of commodity, the form of money, the form of capital, the form of profit, of interest, etc." (Reichelt) This article demonstrates that Kozo Uno and Thomas T. Sekine in Japan, as well as Hans-Georg Backhaus and Helmut Reichelt in Germany, independently discovered "the premature and unnecessary reference to the labour theory of value in the early part of Capital" (Uno), stating that Marx contradicts his own method by establishing that socially necessary labor constitutes the substance of value right at the very beginning of Capital - in the sphere of circulationalthough necessary prerequisites, such as competition, are only available later - in the sphere of production. Finally, Uno's and Sekine's theory of capital is integrated into a system in accordance with Hegel's encyclopedia, involving Hegel's Logic (as logic), Uno's/Sekine's notion of capital (based on Marx) as base/substructure (nature), and a superstructure (spirit).
\end{abstract}

Keywords: Hegel's logic; Marxian theory of value; premature reference to the labor theory of value.

1 All rights reserved. No part of this work may be reproduced, stored in a retrieval system, or transmitted in any form or by any means, electronic, mechanical, photocopying, microfilming, recording or otherwise, without written permission. Please contact the author (mail@kenkubota.de) for permissions.

2 This article is the English translation of the original German paper, which was first published in 2009 and is now available online at https://doi.org/10.4444/100.100.de. Further authors, such as Stapelfeldt, Banaji, and Shamsavari, should be taken into account: "Two other noteworthy Hegelian approaches (which should be taken into account in a revised version of [Kubota, 2009]) are those of Jairus Banaji (India) [Banaji, 1979] and Ali Shamsavari (Iran) [Shamsavari, 1991], described at [Hoff, 2009, pp. 117-119] [Hoff, 2017, pp. 115-117]." (Ken Kubota: Philosophical Bibliography, p. 18.) See also pp. 27 f. (Stapelfeldt), pp. 28 f. (Shamsavari), and p. 31 (Banaji) of my Philosophical Bibliography, also available online at https://doi.org/10.4444/100.110, where future updates will be published.

3 For their many suggestions and assistance with proofreading, I would like to thank the Hegel experts Prof. Andreas Arndt (Berlin, honorary president of the International Hegel Society), Dr. Christian Iber (Berlin, author of a very important commentary on the first two chapters of Hegel's Logic of Essence), and Prof. Michael Wolff (Bielefeld), in addition to the Marx experts Dr. Hans-Georg Backhaus (Frankfurt/Main), Prof. Helmut Reichelt (Bremen), Prof. Thomas T. Sekine (Tokyo), Prof. John R. Bell (Victoria/British Columbia), and Prof. Kiyoshi Nagatani (Tokyo), as well as my friends Edgar Hilsenrath ( $\dagger$ ), at whose desk parts of this article were written, Heinz-Klaus Metzger $(\square)$ and Rainer Riehn $(\square)$, and Jan Hoff. This article and updates will be available online at: https://doi.org/10.4444/100.100.

4 The author is a scientist and philosopher focusing on philosophy and mathematics. He studied philosophy in Berlin. Email: mail@kenkubota.de. Website: https://doi.org/10.4444/100. 
New art is as abstract as social relations have in truth become. ${ }^{5}$

Theodor W. Adorno

Perhaps no other work describes the method in Capital more accurately than Helmut Reichelt's dissertation thesis: "What - this way one might summarize Marx's approach in the form of a question - is hidden in the categories themselves; what is the peculiar content of the economic form determinations, i.e., of the form of commodity, the form of money, the form of capital, the form of profit, of interest, etc.? Whereas bourgeois political economy generally is characterized by its way of grasping the categories in an outward way, Marx insists on a strict deduction of the genesis of these forms - a programmatic concept that instantly calls to mind Hegel's critique of Kant's transcendental philosophy." 6 This concept of a doctrine of categories, i.e., of a theory of forms, is the central methodological moment that builds the relation between Marx and Hegel, and simultaneously, the foundation of Adorno's critique of society and his pleading for a reasonable form of the social division of labor without the "exchange of equivalents."7

The social relevance of the problems caused by capitalism due to an economic anarchy resulting from its private ownership of the means of production was emphasized by the founder of relativity theory and Nobel Prize laureate Albert Einstein in his 1949 essay Why Socialism?, despite an open discussion being difficult at that time: "The economic anarchy of capitalist society as it exists today is, in my opinion, the real source of the evil. [...] In this respect, it is important to realize that the means of production [...] may legally be, and for the most part are, the private property of individuals. [...] Private capital tends to become concentrated in few hands, partly because of competition among the capitalists [...]. The result of these developments is an oligarchy of private capital the

5 Theodor W. Adorno: Aesthetic Theory, p. 31. - Bibliography at the end of this article.

6 " $[\mathrm{W}] \mathrm{as}$ - so könnte man den Marxschen Ansatz in Form einer Frage zusammenfassen - verbirgt sich in den Kategorien selbst; was ist der eigentümliche Gehalt der ökonomischen Formbestimmtheiten, also der Warenform, der Geldform, der Kapitalform, der Form des Profits, des Zinses usw.? Während die bürgerliche politische Ökonomie generell dadurch charakterisiert ist, daß sie die Kategorien äußerlich aufgreift, besteht Marx auf einer strengen Ableitung der Genesis dieser Formen - eine Programmatik, die unmittelbar an Hegels Kritik der Kantischen Transzendentalphilosophie erinnert." (Helmut Reichelt: Zur logischen Struktur des Kapitalbegriffs bei Karl Marx, p. 22, emphases as in the original.) As with Hegel, in the following the notions form and category will be used synonymously. According to Hegel, "the necessary forms and self-determinations of thought are the content and the ultimate truth itself." But the categories are not only subjective, but "equally have objective value and existence." (G. W. F. Hegel: The Science of Logic. Introduction) ("die notwendigen Formen und eigenen Bestimmungen des Denkens [...] der Inhalt und die höchste Wahrheit selbst." "ebensosehr objektiven Wert und Existenz" G. W. F. Hegel: Wissenschaft der Logik. Die Lehre vom Sein (1832), pp. $34 \mathrm{f}$. and Wissenschaft der Logik. In: Werke (im Folgenden HTW), vol. 5, pp. 44 f.)

7 “Tausch von Äquivalenten” (Theodor W. Adorno: Zum Klassizismus von Goethes Iphigenie. In: AGS, vol. 11, p. 508).

\begin{tabular}{|l|l|l|l|l|}
\hline Qevista Dialectus & Ano 9 & n. 18 & Outubro 2020 & p. 39-65 \\
\hline
\end{tabular}


enormous power of which cannot be effectively checked even by a democratically organized political society. This is true since the members of legislative bodies are selected by political parties, largely financed or otherwise influenced by private capitalists [...]. [...] Moreover, under existing conditions, private capitalists inevitably control, directly or indirectly, the main sources of information (press, radio, education). It is thus extremely difficult, and indeed in most cases quite impossible, for the individual citizen to come to objective conclusions and to make intelligent use of his political rights. [...] There is no provision that all those able and willing to work will always be in a position to find employment; an 'army of unemployed' almost always exists. The worker is constantly in fear of losing his job. [...] The profit motive, in conjunction with competition among capitalists, is responsible for an instability in the [...] utilization of capital which leads to increasingly severe depressions. [...] This crippling of individuals I consider the worst evil of capitalism. [...] [U]nder present circumstances, free and unhindered discussion of these problems has come under a powerful taboo [...]."

This treatise does not intend a philological analysis of the writings handed down by Karl Marx, but the logical reconstruction and further development of his approach of a dialectical presentation of the general notion of capital in the context of Georg Wilhelm Friedrich Hegel's philosophy, in particular his main work Science of Logic, the most complex work in the history of philosophy, and of Critical Theory (Kritische Theorie) of the Frankfurt School of Theodor W. Adorno and Max Horkheimer. The results of Marx research that were of the greatest importance internationally are also taken into account: the work of Isaak Illich Rubin, murdered in Russia during the Stalinist purges, the work of Hans-Georg Backhaus and Helmut Reichelt in Germany, and of Kozo Uno and Thomas T. Sekine in Japan. ${ }^{9}$

Both Kozo Uno and his student Thomas T. Sekine as well as - the result of a several-decades-long collaboration with Hans-Georg Backhaus - Helmut Reichelt state at least since 1947 in Japan and since 2002 in Germany, independently of each other, ${ }^{10}$ that

\footnotetext{
Albert Einstein: Why Socialism?, pp. $12 \mathrm{ff}$.

Theorists that are more relevant for reception-history are not considered in this article.

10 However, as early as 1970, as noted by Helmut Reichelt, Klaus Hartmann pointed out the problematic reinterpretation of the relative value into an absolute value: "The reinterpretation of the exchange value into an absolute value as such is an insidiousness, but it is understood from the intention with which value theory is able to do everything that can be done with the price concept. From a philosophical point of view, the concept of value assigned to labor only exists in the term 'value' and actually not yet in the exchange value." ("Die Umdeutung des Tauschwertes in absoluten Wert ist als solche eine Erschleichung, sie versteht sich aber aus der Absicht, mit der Werttheorie alles leisten zu können, was man mit dem Preisbegriff leisten kann. Philosophisch gesehen liegt erst im Begriff 'Wert' und eigentlich
}

\begin{tabular}{|l|l|l|l|l|}
\hline Q Povista Dialectus & Ano 9 & n. 18 & Outubro 2020 & p. 39-65 \\
\hline
\end{tabular}


Marx, in contradiction to his own claim of a strict deduction of categories, does not deduce the determination of value as "socially necessary labor time," 11 but at the very opening of Capital grasps it, like Kant, in an outward fashion - in the chapter on the commodity, already in the description of the sphere of circulation, although such a determination of value is constituted only through competition, which belongs to the subsequent sphere: the sphere of production. This is undoubtedly one of the most essential discoveries in the field of economy since the publication of the first edition of Capital in the year 1867.

Strictly speaking the notion of labor may only appear later, in the sphere of production, since the necessary historical conditions for the presentation of the sphere of circulation are so general, that, like in feudalism, the category of commodity can be deduced without industrial capital, which is characteristic of capitalism and founded on the category of labor. On the presentation level in the sphere of circulation, both Backhaus and Reichelt - again independently - at first attribute only a superindividual validity (Geltung) to the commodity, whereas Sekine attributes significance to the commodity, which here is constituted only relatively, only through the immediate relation of the commodities to each other without reference to the substance of value, and which is not determined further to (socially necessary) labor until the sphere of production.

This is because a correct dialectical presentation is incompatible with a prematurely introduced determination like that of the value as socially necessary labor time in the sphere of circulation. First, categories appear to depend on the anticipated determination, although those are actually some of the requirements of the determination. Second, because of the anticipation, it is no longer recognizable that the premature determination is actually a consequence of those categories. The notion of competition that appears later in Marx's work is a necessary condition for determining the value as socially necessary labor time. The logical connection between competition as a conditio sine qua non and the determination of value as socially necessary labor time as the resulting

noch nicht in dem des Tauschwerts der der Arbeit zugeordnete Wertbegriff vor." - Klaus Hartmann: Die Marxsche Theorie, p. 269.) Also, in 1973, a project group from Hanover emphasized the derivability of the forms of value without reference to the substance of value: "The development of value forms can therefore be derived as a necessary process from the mere form content of the commodity, as it can be empirically determined in exchange without having analyzed its substance." ("Die Entwicklung der Wertformen läßt sich daher als notwendiger Prozeß bereits aus dem bloßen Formgehalt der Ware ableiten, wie er im Tausch empirisch konstatierbar ist, ohne seine Substanz analysiert zu haben." Projektgruppe zur Kritik der politischen Ökonomie: Zur Logik des Kapitals, p. 66.) I thank Michael Heinrich for bringing this to my attention.

11 "[G]esellschaftlich nothwendige[n] Arbeitszeit" (Karl Marx: Das Kapital. Kritik der politischen Ökonomie. Erster Band. Hamburg 1872 (in the following: Das Kapital). In: Karl Marx, Friedrich Engels: Gesamtausgabe (in the following: MEGA²), vol. II/6, p. 73; siehe Karl Marx, Friedrich Engels: Werke (in the following: MEW), vol. 23, p. 53).

\begin{tabular}{|l|l|l|l|l|}
\hline Revista Dialectus & Ano 9 & n. 18 & Outubro 2020 & p. 39-65 \\
\hline
\end{tabular}


consequence is no longer evident in Marx's presentation with the incorrect order of these two categories. The derivability of the forms of commodity and money without the aid of the concept of labor is also obscured. And, thirdly, as in mathematical proof, the proof goal (here the determination of value by labor time) can no longer be achieved, since it has already been assumed as a prerequisite: "If this concept of value [...] is assumed, then the transition to industrial capital must also fail [...]." ${ }^{12}$ Marx does not derive the determination of value as socially necessary labor time, but only takes it up externally. He thus does not live up to his very own claim of a systematic deduction of the categories and its inherent explication of the prerequisites - precisely the claim that fundamentally sets him apart from all other economic theorists of his time. The adherence to a premature introduction of the definition of value as socially necessary labor time, however, belongs, varying a formulation used by Marx, to that which among Marx exegetes is permitted, but logically not permitted.

Isaak Illich Rubin (1886-1937)

A particularly important economist in Russia was Isaak Illich Rubin, who was appointed professor at the first Moscow State University in February 1921. He simultaneously taught at the Institute of the Red Professorship and at the Communist Sverdlov University, and later, in 1926, became a member of the Marx-Engels Institute under the direction of David Riazanov. ${ }^{13}$ His main work is Essays on Marx's Theory of Value, which focuses on methodological problems. ${ }^{14}$ His work was highly valued by the politburo member Bukharin, and the People's Commissioner for National Education Lunacharsky campaigned for Rubin when he was arrested in 1921 in the turmoil during the aftermath of the revolution. Rubin was social democratic, worked in the Jewish workers' organization Bund and was a member of the Moscow City Soviet. He was shot dead during the Stalinist purges on November 27, 1937.

Of outstanding importance is the chapter "Content and Form of Value" in Essays on Marx's Theory of Value. Rubin was fully aware of Marx's approach based on

12 Helmut Reichelt: Marx's Critique of Economic Categories, p. 43.

13 See here and below: Ljudmilla Vasina: I. I. Rubin - Marxforscher und Politökonom, pp. 144 ff.

14 "In the German translation, however, the first part concerning commodity fetishism has been left out. The English [...] or French [...] edition should be used for this section." ("In der deutschen Übersetzung wurde allerdings der erste, den Warenfetischismus betreffende Teil weggelassen. Für diesen Abschnitt sollte die englische [...] oder französische [...] Ausgabe benutzt werden." - Michael Heinrich: Kommentierte Literaturliste zur Kritik der politischen Ökonomie, p. 205, n. 18.) Rubin's writings include the review of a publication by Friedrich Pollock, the friend and collaborator of Adorno and Horkheimer. (See Ljudmilla Vasina: I. I. Rubin - Marxforscher und Politökonom, p. 148.).

\begin{tabular}{|l|l|l|l|l|}
\hline Q & Anosita \\
\hline
\end{tabular}


Hegel's method: "One cannot forget that, on the question of the relation between content and form, Marx took the standpoint of Hegel, and not of Kant. Kant treated form as something external in relation to the content, and as something which adheres to the content from the outside. From the standpoint of Hegel's philosophy, the content is not in itself something to which form adheres from the outside. Rather, through its development, the content itself gives birth to the form which was already latent in the content. Form necessarily grows out of the content itself." ${ }^{15}$ Rubin particularly points out that Marx's achievement is not - as is often assumed - based on the identification of work as a substance or source of value, which is already found in Smith and Ricardo, but that Marx has shown that it is from the historically specific production of commodities this results in the form of value tacitly assumed by the bourgeois economists, ${ }^{16}$ whereby Rubin refers to a quote from the first edition of Capital in the year 1867: " "The social form of commodities and the form of value (Wertform), or form of exchangeability ([F]orm der Austauschbarkeit) are, thus, one and the same['] (Kapital, I, 1867, p. 28; Marx's italics)." 17 The general social form is the form of value, the concrete with an independent shape is the exchange value. ${ }^{18}$

However, Rubin makes several mistakes in analyzing Marx's use of Hegel's dialectical method. First, he recognizes the problem that Marx assumes both the vertical concept of value with labor as substance of value and the horizontal concept of value as a merely relational equation: ${ }^{19}$ "We have reached the paradoxical position that Marx sometimes takes social (or socially equalized) labor, and sometimes abstract labor, as the content of value." ${ }^{20}$ Rubin regards this contradiction as resolved by the distinction between analysis and synthesis. The dialectical method includes "analysis as well as synthesis," but as a unity in every dialectical transition from one form to the next. Therefore one cannot regard, as Rubin does, the first transition as an analysis of the exchange value (the form), in which "by means of analysis he uncovers the content," 21 and the second transition as a

15 Isaak Illich Rubin: Essays on Marx’s Theory of Value, p. 117.

16 See ibid., pp. $120 \mathrm{f}$.

17 Ibid., p. 115, emphases as in the original. ("Gesellschaftliche Form der Waare und Werthform oder Form der Austauschbarkeit sind also eins und dasselbe." - Karl Marx: Das Kapital. Kritik der politischen Ökonomie. Erster Band. Hamburg 1867 (in the following: Das Kapital, first edition from 1867). In: $\mathrm{MEGA}^{2} \mathrm{II} / 5$, p. 38.)

18 See ibid., p. 116. Rubin uses the term value both for the value form and for value as the overarching unity of value form and value substance. For the sake of readability, it is only used here in the latter sense.

19 For the logical foundation, see Christian Iber: Grundzüge der Marx'schen Kapitalismustheorie, p. 35, n. 13.

20 Isaak Illich Rubin: Essays on Marx’s Theory of Value, p. 118.

21 Ibid., p. 112.

\begin{tabular}{|c|c|c|c|c|}
\hline Rovista Dialectus & Ano 9 & n. 18 & Outubro 2020 & p. $39-65$ \\
\hline
\end{tabular}


synthesis, which represents the step "from content to form." 22 Already Backhaus has recognized this second transition from the second to the third subsection of the first chapter from the second edition of Capital as no longer necessary.

Furthermore, Rubin always assumes a capitalist production of commodities. However, dialectical presentation means the ascent "from the abstract to the concrete," 23 so that the notion receives exactly one further determination at each level. But this results in an explicit inclusion of the historically specific conditions and not in a "tacit assumption" 24 of the production of commodities. Moreover, since historically specific conditions are only introduced in a dialectical presentation as soon as they are required in the sequence, certain parts of the representation are not only limited to the capitalist production of commodities, but are also valid for other historical epochs. Commodities (interchangeable objects) also existed in feudalism. Rubin therefore could not assume a developed production of commodities right at the beginning of the presentation. ${ }^{25}$

\section{Hans-Georg Backhaus}

Hans-Georg Backhaus ${ }^{26}$ studied at the Johann Wolfgang Goethe University in Frankfurt and completed his studies, under the supervision of Adorno, with a diploma thesis on Marx's theory of value finalized in 1968, the approach of which he further specified in a dissertation thesis. ${ }^{27}$ His acquaintance with Helmut Reichelt during their studies marked the beginning of a long-term friendship and cooperation in research in the field of philosophy and political economy. Backhaus worked as a research assistant at the universities of Frankfurt and Bremen.

With his investigations into Marx's theory of value, which also includes money and capital theory, he introduced the "New Marx Reading" in German-speaking countries, which, beyond Stalinist orthodoxy and other dogmatic simplifications, is the program of a reconstruction of Marx's unfinished value theory on the basis of Hegel's (Science of) Logic and the Critical Theory of Adorno and Horkheimer, and, in particular, addresses

Ibid., p. 113.

3 “[V]om Abstrakten zum Concreten." (Karl Marx: Einleitung [zu den Grundrissen der Kritik der politischen Ökonomie]. In: MEGA² II/1.1, p. 36, see MEW 13, p. 632.)

24 Isaak Illich Rubin: Essays on Marx's Theory of Value, p. 110.

25 In his criticism of Rubin, Kiyoshi Nagatani has already pointed out that the capitalist production process can only be developed with labor as a commodity. See Kiyoshi Nagatani: Fallacy of Rubin's Value Theory, p. 2. I thank Prof. Nagatani for granting permission for the unpublished text to be quoted.

26 I thank Hans-Georg Backhaus, whom I - like Prof. Reichelt - met in person for the first time in March 1998 , for the generous amount of information he shared.

27 See Hans-Georg Backhaus: Zuvor: Die Anfänge der neuen Marx-Lektüre. In: Dialektik der Wertform, p. 31 .

\begin{tabular}{|c|c|c|c|c|}
\hline QRovista Dialectus & Ano 9 & n. 18 & Outubro 2020 & p. 39-65 \\
\hline
\end{tabular}


methodological questions. The starting point of this research in the field of Marxian value theory is Backhaus' essay Zur Dialektik der Wertform (On the Dialectics of the ValueForm $)^{28}$ originally published in 1969 , which is based on a presentation that he gave in one of Adorno's main seminars in the winter semester of $1964 / 65$. In it, he addressed the meaning of the concept of form in value theory for the first time as well as the hitherto largely unknown first edition of Capital and the associated problems. Backhaus was one of the initiators of the Marx-Gesellschaft (Marx Society) founded in $1994 .^{29}$

The main results of Hans-Georg Backhaus' research are:

1. Form theory: The economic categories are forms (forms of value, e.g., the form of commodity, the form of money, the form of capital, the form of profit, of interest, etc.), which, like the categories used by Hegel, are to be strictly deduced.

2. Logical development: The evidence is presented in a dialectical presentation - apart from a few historically contingent assumptions - logically, non-empirically.

3. Absolute notion of value: The notion (or concept) of value (and thus all economic categories) is, like Hegel's notion of the notion, subjective and objective at the same time, i.e., absolute. ${ }^{30}$ The real constitution of economic categories is therefore independent of (un)consciousness.

4. Double concept of criticism: On the one hand, the economic categories are to be criticized in (bourgeois) theory, insofar as they are not systematically derived, and, on the other hand, in reality, insofar as they are restrictive.

5. Critique of pre-monetary value theory: From the category of commodity follows necessarily that of money, ${ }^{31}$ and from this, that of capital. Money shows itself in the presentation of the failure of the exchange process of pre-monetary commodities as a necessary consequence, as well as a necessary condition for capital, which results in the non-neutrality of money.

28 See Hans-Georg Backhaus: On the Dialectics of the Value-Form, pp. 99-120. (See Hans-Georg Backhaus: Zur Dialektik der Wertform. In: Dialektik der Wertform, pp. 41-64.).

29 See www.marx-gesellschaft.de.

30 Marx himself speaks of "objective forms of thought," that is, subjective-objective forms: "Such forms as these constitute precisely the categories of bourgeois economy. They are the socially valid - thus objective - forms of thought, for relationships of production of this particular historically determined social mode of production." (Karl Marx: Capital (1867). Vol. 1. Chapter 1: The Commodity, translation of the first German edition) ("Derartige Formen bilden eben die Kategorien der bürgerlichen Oekonomie. Es sind gesellschaftlich gültige, also objektive Gedankenformen für Produktionsverhältnisse dieser historisch bestimmten gesellschaftlichen Produktionsweise." - Karl Marx: Das Kapital, Erstausgabe von 1867. In: MEGA ${ }^{2} I / 5$, p. 47.) For Hegel's subjective-objective categories, see note 6.

31 Strictly speaking, according to Backhaus, we are dealing with the reduplication of the commodity-in-itself into commodity and money. This also solves the "problem" of the money commoditiy: The objectivity that the value must take on is the outward appearance of the sphere of circulation, specifically the exchangeability of the commodity-in-itself, which applies to both commodity and money. Money is commodity-in-itself (as the overarching third above commodity and money), but not commodity as opposed to money. This also applies to capital, which is also exchangeable in all three phases $(\mathrm{G}-\mathrm{W}-$ G'), i.e., is commodity-in-itself.

\begin{tabular}{|l|l|l|l|l|}
\hline Qevista Dialectus & Ano 9 & n. 18 & Outubro 2020 & p. 39-65 \\
\hline
\end{tabular}


6. Independence of the value: Like Hegel speaks of the autonomisation (Verselbständigung) of the notion of the notion, Backhaus and Reichelt speak of an "increasing independence of the value." 32 In order to maintain itself, the value must free itself from the restrictive binding to concrete use values, as it already becomes clear with the category of money.

In the field of Marx philology, Backhaus developed the "popularization thesis" according to which Marx had simplified his value theory for readers - Marx himself explicitly wrote at the beginning of the preface to the first edition of Capital: "I have popularized the passages concerning the substance of value and the magnitude of value as much as possible." ${ }^{33}$ Backhaus states an "inadequate mediation of substance and form of value;" even the "transition from the second to the third section of the first chapter" is no longer a "necessary transition.".34

Backhaus and Reichelt drew attention to "the problem of the supra-individual validity of economic units" 35 as early as 1994. They argue that only if the determinations of value are not only subjective, but also had supra-individual, i.e., in this context, objective validity, the dialectical contradiction arises, which drives the development of categories, according to Backhaus in an article from $1996,{ }^{36}$ in which he refers to the meaning of the concept of validity for the sphere of circulation: "Equivalence, supraindividual validity and inter-temporal existence, these 'general characteristics of value,' which are taboo in the subjective and formalistic economics, form the real topic of Marx's theory of value at the level of investigation of "simple circulation." ,37

32 "[Z]unehmenden Verselbständigung des Wertes." (Hans-Georg Backhaus, Helmut Reichelt: Wie ist der Wertbegriff in der Ökonomie zu konzipieren?, p. 81.).

33 "[D]ie Analyse der Werthsubstanz und der Werthgröße [...] möglichst popularisirt." (Karl Marx: Das Kapital. In: MEGA² II/6, p. 65, see MEW 23, p. 11.) See also Gerhard Göhler: Die Reduktion der Dialektik durch Marx, pp. $160 \mathrm{ff}$.

34 "[M]angelhafte Vermittlung von Substanz und Form des Werts;" "Übergang vom zweiten zum dritten Abschnitt des ersten Kapitels" als ein "notwendiger Übergang nicht mehr einsichtig." (Hans-Georg Backhaus: Zur Dialektik der Wertform. In: Dialektik der Wertform, p. 43.).

35 "[D]as Problem der überindividuellen Geltung der ökonomischen Einheiten." (Hans-Georg Backhaus, Helmut Reichelt: Der politisch-ideologische Grundcharakter der Marx-Engels-Gesamtausgabe, p. 114, emphasis by the author.).

36 See Hans-Georg Backhaus: Die Irrtümer der nationalökonomischen Marx-Kritik als Grundmängel der nationalökonomischen Theoriebildung, p. 37.

37 "Äquivalenz, überindividuelle Geltung und intertemporale Existenz, diese in der subjektiven und formalistischen Ökonomie tabuisierten 'allgemeinen Charaktere des Werts,' bilden auf der Untersuchungsebene der 'einfachen Zirkulation' das eigentliche Thema der Marxschen Werttheorie." (Ibid., p. 47.).

\begin{tabular}{|l|l|l|l|l|}
\hline Qenista Dialectus & Ano 9 & n. 18 & Outubro 2020 & p. 39-65 \\
\hline
\end{tabular}


Helmut Reichelt

Helmut Reichelt ${ }^{38}$ studied in Freiburg (in Breisgau), in Frankfurt/Main with Adorno and Horkheimer among others, and also intermittently in the U.S., and later taught until his retirement as professor of sociology at the University of Bremen. While he was studying in Frankfurt, his friend Hans-Georg Backhaus made him aware of Marx, and after completing his Diplom in 1966, a doctorate followed with Iring Fetscher in 1968 with Zur logischen Struktur des Kapitalbegriffs bei Karl Marx (On the Logical Structure of the Notion of Capital in Karl Marx) published in 1970. In this work, he provided evidence for German-speaking countries that Engels had misunderstood the surface of the simple commodity circulation (the sphere of circulation) as simple commodity production, i.e., as pre-capitalist production of commodities. ${ }^{39}$

Apart from the achievements of his long-term cooperation with Hans-Georg Backhaus, his more recent works since 2001, which result in a demand for a clear separation of the circulation sphere from the production sphere that Marx combined, are of particular importance. In the 2001 foreword to the new edition of his doctoral thesis, ${ }^{40}$ Reichelt emphasized that Marx still distinguished the "exchange-value-setting traffic" from the "exchange-value-setting work" in the rough draft (Rohentwurf/Grundrisse), and that there is also the problem at the level of economic science that Klaus Hartmann had already pointed out in 1970 in Die Marxsche Theorie (Marx's Theory), namely that the exchange value as a merely relational (horizontal), mediating category of the sphere of circulation, in contrast to the "absolute" (vertical) value, could not be added to labor as a substance of value in the sphere of production in the context of a macroeconomic overall calculation. ${ }^{41}$ However, since Marx already mixed both spheres in the first chapter of Capital, a dialectical representation was no longer possible; the method had to be "hidden."

The decisive breakthrough was achieved by Reichelt, after a long collaboration with Hans-Georg Backhaus, in his essay on the problem of validity from 2002, showing that if Marx already in the sphere of circulation "proceeds on the basis that commodities

38 According to Prof. Reichelt, there is no reference to Rubin in his writings. Also, Backhaus' work - with the exception of his diploma thesis - does not deal with Rubin's theory in detail. The name Rubin can only be found in a list of authors "who merely give a lecture on terms 'related to the labor theory of value'." ("[D]ie lediglich 'arbeitswerttheoretische' Begriffe referieren." (Hans-Georg Backhaus: Materialien zur Rekonstruktion der Marxschen Werttheorie. In: Dialektik der Wertform, p. 95. See ibid., p. 120, n. 6.).

39 See Helmut Reichelt: Zur logischen Struktur des Kapitalbegriffs bei Karl Marx, pp. 276 ff.

40 See Helmut Reichelt: Vorwort zur Neuauflage. In: Zur logischen Struktur des Kapitalbegriffs bei Karl Marx, pp. 7-18.

41 According to Brentel, use value is "itself always a relational category." ("[S]tets selbst schon eine relationale Kategorie." - Helmut Brentel: Soziale Form und ökonomisches Objekt, p. 322.).

\begin{tabular}{|l|l|l|l|l|}
\hline Q Rovista Dialectus & Ano 9 & n. 18 & Outubro 2020 & p. 39-65 \\
\hline
\end{tabular}


are the products of capital," 42 and with the illegitimate anticipation of the determination of the value as socially necessary labor time, the dialectical presentation must fail at a later point: "Already in the Grundrisse [...] Marx assumes that value is the same as the magnitude of value, and this is determined according to the socially-necessary labour-time. This, however, is only implemented as a regulating principle in a developed capitalism $[\ldots]$, that is, in competition. If this concept of value [...] is assumed, then the transition to industrial capital must also fail [...]." ${ }^{43}$ That "linking this concept of value with the constitutive abstraction carried out by agents engaged in exchange can no longer be mediated" is "expressed indirectly in crude formulations, typically in the presentation of the exchange process as the 'true relation between commodities,' where Marx again refers back to his analysis of the commodities in the first chapter, namely that 'the natural laws of the commodity have manifested themselves in the natural instinct of the owners of commodities." "44 This problem can only be solved with the help of the notion of value as a notion of validity - a possibility that is obstructed in Capital due to the deficient presentation: "This implies that Marx always already proceeds on the basis that commodities are the product of capital, in other words that value is the objectification of the abstract-universal labour of the labourer. The concept of value derived from this conception is a precondition for the structural organisation of the argument and cannot be introduced as a concept of validity. Validity can only be isolated as a central theme within the context of the process of circulation, as the starting point and prerequisite for the development of a labour value theory in which abstract-universal labour and labour-time can likewise still be developed from the validity conception of value." ${ }^{45}$ Conversely, the concept of labor in the sphere of circulation can be

42 Helmut Reichelt: Marx's Critique of Economic Categories, p. 43.

43 Ibid., pp. $42 \mathrm{f}$.

44 Ibid., p. 43. Uno, as well as the Hanover project group from 1973, independently drew the right conclusions and removed the second chapter of Capital (exchange process) from the presentation due to its lack of relevance for the logical development: "The previous chapter in the structure of Marx's presentation on the exchange process interrupts the logical sequence of the categories and describes, on the level of empirical exchange, historical development processes of simple circulation. From the development of the general form of value, the argumentation must therefore be continued directly with the first function of money as a measure of value." ("Das in der Struktur der Marxschen Darstellung vorhergehende Kapitel über den Austauschprozeß unterbricht die logische Abfolge der Kategorien und beschreibt auf der Ebene des empirischen Tausches historische Entwicklungsprozesse der einfachen Zirkulation. Von der Entwicklung der allgemeinen Wertform ist daher die Argumentation direkt mit der ersten Funktion des Geldes als Maß der Werte fortzuführen.” - Projektgruppe zur Kritik der politischen Ökonomie: Zur Logik des Kapitals, p. 80, n. 89.).

45 Helmut Reichelt: Marx's Critique of Economic Categories, pp. $31 \mathrm{f}$. At the same time, traits of the original argument still shine through in Marx. The project group in Hanover comments on this: "Introducing the commodity as a product of capital into the investigation would mean subordinating the provisions of capital without further ado, rather than developing them from the form determinations of

\begin{tabular}{|l|l|l|l|l|}
\hline Q Povista Dialectus & Ano 9 & n. 18 & Outubro 2020 & p. 39-65 \\
\hline
\end{tabular}


dispensed with: "It can be assumed that these things 'determined as exchange values' are products of labor, but Marx determines labor in the context of simple circulation in a completely different way than later in Capital. Labor is not yet of central importance for the development of the (first) categories, so that the concept of capital in its most abstract form can also be developed without relying on labor." 46

\section{Kôzô Uno (1897-1977)}

The greatest contribution to political economy in the 20th century was made by Kôzô Uno with his reconstruction and immanent critique of Marx's notion of capital. He studied at the most prestigious university in Japan, the University of Tokyo, where he later taught as a professor, and in Berlin. During his student years in Tokyo, he got hold of a copy of Capital, a book he had been trying to read and understand since then. ${ }^{47}$

Before World War II, the Marxist debate in Japan was dominated by a dispute between the party-official Kôza group, ${ }^{48}$ according to which Japanese capitalism was based on feudal foundations, and the oppositional Rônô group, ${ }^{49}$ which predicted that the feudal remnants in advancing capitalism would gradually disappear over time. Uno knew better: Even in capitalism, atavistic moments can exist depending on certain historical conditions. However, these moments and conditions are the subject of a different level of abstraction than that of Capital. Uno distinguishes three levels ("three-step approach"50): the "pure theory" of capitalism - to which Marx's Capital belongs -, the stages theory with the sequence of historical phases, and, finally, the concrete empirical analysis. The

simple commodities. [...] Marx, however, abstracts from the fact that commodities in capitalist society are the product of capital in order to be able to trace the genesis of capital from the determinations of simple commodities as the nucleus of the bourgeois mode of production and not to have to assume capital as a finished relationship." ("Die Ware als Produkt des Kapitals in die Untersuchung einzuführen hieße, die Bestimmungen des Kapitals kurzerhand $\mathrm{zu}$ unterstellen, statt sie aus den Formbestimmungen der einfachen Ware zu entwickeln. [...] Marx abstrahiert jedoch von der Tatsache, daß die Waren in der kapitalistischen Gesellschaft Produkt des Kapitals sind, um die Genesis des Kapitals aus den Bestimmungen der einfachen Ware als der Keimform der bürgerlichen Produktionsweise nachzeichnen zu können und das Kapital nicht als fertiges Verhältnis unterstellen zu müssen." - Projektgruppe zur Kritik der politischen Ökonomie: Zur Logik des Kapitals, pp. 56 f.).

46 “Dass diese als 'Tauschwerte gesetzten' Dinge Arbeitsprodukte sind, kann unterstellt werden, aber Marx bestimmt Arbeit im Kontext der einfachen Zirkulation in ganz anderer Weise als später im Kapital. Die Arbeit hat für die Entwicklung der (ersten) Kategorien noch keine zentrale Bedeutung, sodass auch der Kapitalbegriff in seiner abstraktesten Gestalt entwickelt werden kann, ohne auf Arbeit zu rekurrieren." (Helmut Reichelt: Neue Marx-Lektüre, pp. 154 f., emphasis as in the original.).

47 On Uno and his school, see also Jan Hoff: Marx Worldwide, pp. 97-115. See also John R. Bell: Capitalism and the Dialectic.

48 The term Kôza (lectures/series) originates from the title of the group's seven-volume work.

49 After the Rônô (Workers and Peasants) journal, around which members had formed their group.

50 Thomas T. Sekine, Uno-Riron: A Japanese Contribution to Marxian Political Economy, p. 853. I thank Thomas Sekine for sending me this article.

\begin{tabular}{|l|l|l|l|l|}
\hline Q Rovista Oialectus & Ano 9 & n. 18 & Outubro 2020 & p. 39-65 \\
\hline
\end{tabular}


THE DIALECTICAL PRESENTATION OF THE GENERAL NOTION

Ken Kubota

\begin{tabular}{|l|l|}
\hline \multicolumn{2}{|c|}{ Principles of Political Economy (Uno) } \\
\hline \multirow{2}{*}{$\begin{array}{l}\text { The } \\
\text { Doctrine of } \\
\text { Circulation }\end{array}$} & Commodity \\
\cline { 2 - 2 } & Money \\
\cline { 2 - 2 } The & Capital \\
\hline $\begin{array}{l}\text { Doctrine of } \\
\text { Production }\end{array}$ & The Production-Process of Capital \\
\cline { 2 - 2 } & The Circulation-Process of Capital \\
\cline { 2 - 2 } $\begin{array}{l}\text { The } \\
\text { Doctrine of } \\
\text { Distribution }\end{array}$ & Profit \\
\cline { 2 - 2 } & Rent \\
\cline { 2 - 2 } & Interest \\
\hline
\end{tabular}

stages theory addresses the different phases of capitalism mercantilism, liberalism, and imperialism - depending on the dominating form of capital, i.e., of merchant capital, industrial capital, and financial capital. ${ }^{51}$ The accumulation of capital, for example, can already be shown in pure theory and accordingly takes place in all phases of capitalism, but the formation of monopolies in imperialism happens over time and therefore belongs to the stages theory. ${ }^{52}$

Under the title Principles of Political Economy (Keizai Genron), Uno's main work appeared in two volumes in 1950 and 1952, as did a version reduced to one third of the size of the original work in 1964, which was to serve as a general framework for a comprehensive revision and has been available in English translation since 1980. ${ }^{53}$ Almost 50,000 copies of the "older" Principles sold before the new volume was published and became one of the most controversial and influential writings among Marxist thinkers in post-war Japan. ${ }^{54}$ In contrast to Capital, with its literary language, its numerous allusions and historical dates and excursions, ${ }^{55}$ Uno focuses on the logical structure - the dialectic of capital - and distinguishes the three spheres of the notion of capital: "(1) how capital emerges in an exchange economy (Doctrine of Simple Circulation); (2) how capital

51 See ibid., pp. $853 \mathrm{f}$.

52 See ibid., p. 850.

53 See Kozo Uno: Principles of Political Economy. Theory of a Purely Capitalist Society.

54 See Thomas T. Sekine: Translator's Foreword: In: Kozo Uno: Principles of Political Economy, p. vii. With the end of the authoritarian regime in Japan after World War II, research was able to develop freely, and soon the Marxists accounted for around 50\% of economists, about 20\% of whom belonged to the Uno school, which had always turned against Stalinist dogmatism and was therefore particularly attractive to young scientists. Traditionally, there are essentially three Marxist currents in Japan. The orthodox party loyalists and the Civil Society Group, which is not primarily concerned with a logical reconstruction of the notion of capital, are competing with the Uno school. (See Setsuo Furihata: Entwicklung des japanischen Kapitalismus und marxistische Wirtschaftswissenschaft in Japan, pp. 80 ff.).

55 "In order to locate Capital as the principles of the capitalist economy, we must purify Marx's Capital, by setting aside Marx's references to historical changes, by eliminating his ideological forecasts and prejudices, and by removing his logical inconsistencies." (Shohken Mawatari: The Uno School: a Marxian approach in Japan, p. 406.).

\begin{tabular}{|c|c|c|c|c|}
\hline Revista Dialectus & Ano 9 & n. 18 & Outubro 2020 & p. $39-65$ \\
\hline
\end{tabular}


subsumes the process of production (Doctrine of Production); and (3) how the surplus of production may be divided in the capitalist market (Doctrine of Distribution)."

While Uno had already criticized Marx's value form analysis in his book The Theory of Value (Kachi-Ron) in 1947, with his view of the method of the ascending development of the notion (or concept) based on Hegel, he also proved to be a master of dialectical thinking, whose reconstruction of the notion of capital in structure shows a striking resemblance to Hegel's Science of Logic, even if Uno never explicitly stated the obvious parallels. Some of his results are explained below as examples. ${ }^{57}$ Worldwide, Uno was the first to notice the illegitimate anticipation of the determination of value as socially necessary labor time within the sphere of circulation, in which this determination, according to Hegel's method, cannot be deduced, but only grasped in an outward fashion, like Kant. ${ }^{58}$ The notion of labor, and thus the notion of the substance of value, could not be introduced until the sphere (or doctrine) of production. ${ }^{59}$ Consequently, commodities could only be related to each other relatively - without recourse to labor as the substance of value - and the sphere of circulation, with its categories commodity, money, merchant capital and money-lending capital, thus constituted a theory up to but excluding the category of industrial capital, in which labor as a commodity is introduced, that applies to all areas of a society in which there is exchange, including feudalism. At the same time, Uno correctly locates the three forms of capital - merchant capital, money-lending capital, and industrial capital forming the transition to the sphere of production - in the sphere of circulation, while Marx relegated the first two to the third volume of Capital. The doctrine of the fetish character of the commodity with only an epistemological character and without an economic function - according to Backhaus "to be understood in terms of content only as a

56 Thomas T. Sekine, Uno-Riron: A Japanese Contribution to Marxian Political Economy, p. 861.

57 A list of deviations from Marx can be found on the last two pages of the English translation. See Kozo Uno: Principles of Political Economy, pp. $223 \mathrm{f}$.

58 Uno mentions "the premature and unnecessary reference to the labour theory of value in the early part of Capital." (Kozo Uno: Principles of Political Economy, p. xxiv.).

59 The substance of value can therefore not be understood as abstract labor that is objectified in a commodity, but as the foundation for the "determination of value through price movement": "To solve this problem, we first must recognize that abstract labor as the substance of [value] [...] never means that abstract labor literally congeals or crystallizes into a value. In other words, value is not objectified labor. Value is a determinant of price movement, which is demonstrated in the theories of value-form and measure of value without recourse to labor. The substance of value means that abstract labor or socially necessary labor is the foundation of this determination of value through price movement. Abstract labor never transforms into value. Therefore, the concept 'labor values' is wrong. That abstract labor is objectified in a commodity or abstract labor creates value is a mere metaphorical expression." (Kiyoshi Nagatani: Fallacy of Rubin's Value Theory, p. 3.).

\begin{tabular}{|c|c|c|c|c|}
\hline Rovista Dialectus & Ano 9 & n. 18 & Outubro 2020 & p. $39-65$ \\
\hline
\end{tabular}


part of the third section that became independent" ${ }^{\circ 0}$ - is consequently omitted in the description of the structure of the notion of capital by Uno, without ignoring its content. ${ }^{61}$

Uno knew that the three spheres of circulation, production, and distribution in Marx's Capital logically have the same relationship to each other as the Logic of Being, the Logic of Essence, and the Logic of Notion of Hegel's Science of Logic, namely that of surface, mediation and depth structure. As is well known, Hegel derives the rules of inference of formal logic in the Logic of Notion, which sublates the Logic of Being and the Logic of Essence. The same situation applies to the competition between capitals: This presupposes, on the one hand, competition in the sphere of circulation and, on the other hand, the law of value of the sphere of production, and therefore belongs to the sphere of distribution with "the resurrection of circulation relations based on the law of value." 62

As a Marxist movement of fundamental theoretical importance, the Uno school has numerous representatives, including Setsuo Furihata, Shigekatsu Yamaguchi, Makoto Itoh, and Shohken Mawatari, who taught at central universities and whose teaching was therefore widely disseminated. Other students of Uno are Kiyoshi Nagatani and Thomas T. Sekine, whose reformulation of Uno's theory is the only one that retains the original structure. ${ }^{63}$

\section{Thomas T. Sekine}

Thomas T. Sekine ${ }^{64}$ studied and completed his Ph.D. in Japan, Canada, and Great Britain ${ }^{65}$ and later taught as a university professor in Canada and Japan. He first met Uno during his studies in the years $1955-56 .{ }^{66}$ Sekine's main work is The Dialectic of

60 "[I]hrem Inhalt nach nur als verselbständigter Teil des dritten Abschnitts zu verstehen" (Hans-Georg Backhaus: Zur Dialektik der Wertform. In: Dialektik der Wertform, p. 45).

61 "Thus men are governed by a law that they themselves create; this fact lies at the root of what Marx calls the 'fetishistic character' of a commodity-economy." (Kozo Uno: Principles of Political Economy, p. 27.)

62 "Competition between capitals in search of maximum profit belongs to the third level of theory of capitalism. This implies that competition between capitals is not directly production relations, but the resurrection of circulation relations based on the law of value." (Kiyoshi Nagatani: Fallacy of Rubin's Value Theory, p. 4.)

63 There are also many works that take up Uno's "pure theory" of capitalism and try to develop it further. However, they are all wrong in their deviations from Uno, since the points they put forward make no economic sense.

64 The actual Japanese name of Thomas T. Sekine, whom I first met in Canada in 1996, is Tomohiko Sekine. I thank him for sharing so much information with me. According to him, there is no reference to Rubin in Uno's works; he - Sekine - himself became aware of Rubin in Canada, but sees few parallels with Uno. A mutual reception of the Japanese Uno school and the German field of research around Backhaus and Reichelt is not yet available. The author established the first contact.

65 B.A. at Hitotsubashi University, M.A. at McGill University, Ph.D. at the London School of Economics (LSE).

66 See Thomas T. Sekine: Uno-Riron: A Japanese Contribution to Marxian Political Economy, pp. $848 \mathrm{f}$.

\begin{tabular}{|l|l|l|l|l|}
\hline Q Rovista Oialectus & Ano 9 & n. 18 & Outubro 2020 & p. 39-65 \\
\hline
\end{tabular}


Capital published in two volumes in 1984/1986 (of which a new edition is forthcoming soon). ${ }^{67} \mathrm{~A}$ version written for a wider audience is An Outline of the Dialectic of Capital published in two volumes in 1997.

Sekine's main contribution primarily consists in the reworking of Uno's theory for a Western audience, whereby two aspects constitute the point of reference: The philosopher Hegel stands for the method of dialectical presentation, and the economist Walras stands for the mathematically precise formulation of the general equilibrium theory. Further, Sekine, probably for the first time explicitly, points out the correspondence between Hegel's Science of Logic and Uno's work, which Uno himself did not mention. ${ }^{68}$

67 Further information on the new edition of The Dialectic of Capital is available at https://doi.org/10.4444/34.1.

68 See Thomas T. Sekine: The Dialectic of Capital, vol. 1, p. iv. According to Sekine, Uno's decision not to refer to the correspondence on Hegel's Logic was probably based on strategic considerations. 


\begin{tabular}{|c|c|c|}
\hline \multicolumn{3}{|c|}{ The Dialectic of Capital (Sekine) } \\
\hline \multirow{9}{*}{$\begin{array}{l}\text { The Doctrine of } \\
\text { Circulation }\end{array}$} & \multirow[t]{3}{*}{ Commodity } & Value and Use-Value \\
\hline & & The Forms of Value \\
\hline & & Money Prices \\
\hline & \multirow[t]{3}{*}{ Money } & Measure of Value \\
\hline & & Medium of Circulation \\
\hline & & Store of Value \\
\hline & \multirow[t]{3}{*}{ Capital } & Merchant Capital \\
\hline & & Money-Lending Capital \\
\hline & & Industrial Capital \\
\hline \multirow{9}{*}{$\begin{array}{l}\text { The Doctrine of } \\
\text { Production }\end{array}$} & \multirow{3}{*}{$\begin{array}{l}\text { The Production-Process } \\
\text { of Capital }\end{array}$} & Labour-and-Production Process \\
\hline & & Value Formation and Augment. \\
\hline & & Dev. of Capitalist Method of Prod. \\
\hline & \multirow{3}{*}{$\begin{array}{l}\text { The Circulation-Process } \\
\text { of Capital }\end{array}$} & Circular Motion of Capital \\
\hline & & Turnover of Capital \\
\hline & & Circulation of Surplus Value \\
\hline & \multirow{3}{*}{$\begin{array}{l}\text { The Reproduction- } \\
\text { Process of Capital }\end{array}$} & Reprod. of Capitalist Prod.-Rel. \\
\hline & & Reprod. of Goods as Commodities \\
\hline & & Actual Process of Cap. Accum. \\
\hline \multirow{9}{*}{$\begin{array}{l}\text { The Doctrine of } \\
\text { Distribution }\end{array}$} & \multirow[t]{3}{*}{ Profit } & Rate of Profit \\
\hline & & Formation of Prices \\
\hline & & Rate of Profit and Tech. Progress \\
\hline & \multirow[t]{3}{*}{ Rent } & First Form of Differential Rent \\
\hline & & Second Form of Differential Rent \\
\hline & & Absolute Rent \\
\hline & \multirow[t]{3}{*}{ Interest } & Loan-Capital and Interest \\
\hline & & Commercial Capital and its Profit \\
\hline & & Interest-Bearing Capital \\
\hline
\end{tabular}


As early as 1975 , Sekine had mentioned a "premature reference to the labor theory of value" 69 in the doctrine of circulation, and in 1986 he goes even further and refers - like Backhaus and Reichelt with their notion of value as validity - to value in the sphere of circulation as social significance ${ }^{70}$ instead of socially necessary labor time. Uno, too, restricted the use of the notion of labor to the sphere of production, but did not offer his own terminology as replacement. ${ }^{71}$ Further, Sekine is also aware of the multiple use of the term form by Marx as economic category, on the one hand, and in the sphere of circulation as exchangeability on the other. ${ }^{72}$

Therefore, although Sekine does not primarily consider himself a Hegel specialist, and although Hegel experts may not agree with all of his methodological considerations, The Dialectic of Capital from 1986 may be seen as very elaborated reflections on current economic theory.

Conclusion

Philosophy is "its time apprehended in thoughts," "73 writes Hegel, and nothing else is intended by Horkheimer's project of a new dialectical logic. If "the core of truth is historical," 74 a dialectical presentation of the categories must be formulated according to the historical status.

69 Thomas T. Sekine: Uno-Riron: A Japanese Contribution to Marxian Political Economy, p. 862.

70 "The concept of value at this stage as some unspecified social substance i.e., as a quality which may be called social worth or significance (or even moneyness) is admittedly abstract and difficult to grasp. Even Marx himself could not resist the temptation to identify that substance as abstract human labour at the very opening of Capital. But such a procedure contradicts the method of the dialectic which requires that a self-synthesising totality should first be examined in its immediacy or external form, i.e., by the categories of its 'being.' True to this method Marx correctly began his dialectic of capital with the circulation-form of the commodity, not with production or labour. If one follows Marx in this respect, it is impossible to relate the concept of value, at this abstract stage of the analysis, with such substantive economic activities as labour and production which do not belong to the sphere of simple circulation." (Thomas T. Sekine: The Dialectic of Capital, vol. 1, p. 119.).

71 In his "older" Principles, Uno only refers to Marx's concept of "qualitative unity" ("qualitative Einheit" Karl Marx: Das Kapital. In: MEGA² II/6, p. 110, n. 31, see MEW 23, p. 94, n. 31).

72 For the problem of the dialectical transition of the categories here in relation to the so-called "transformation problem," see Thomas T. Sekine: The Dialectic of Capital, vol. 2, pp. 39-46. Sekine writes on the concept of form as exchangeability in the sphere of circulation: "Uno therefore banishes all references to production from his Doctrine of Simple Circulation, which therefore contains nothing but the forms of commodity, money and capital." (Thomas T. Sekine: Uno-Riron: A Japanese Contribution to Marxian Political Economy, p. 862, emphasis as in the original.).

.$^{73}$ G. W. F. Hegel: Philosophy of Right. Preface. (Philosophie ist "ihre Zeit in Gedanken erfaßt." G. W. F. Hegel: Grundlinien der Philosophie des Rechts. In: HTW, vol. 7, p. 26.)

74 Max Horkheimer and Theodor W. Adorno: Dialectic of Enlightenment, p. ix. ("Zeitkern" - Max Horkheimer, Theodor W. Adorno: Dialektik der Aufklärung. In: Horkheimer: Gesammelte Schriften (in the following: HGS), vol. 5, p. 13.) For information on the difference between the first edition from 1944 and the modified text variant from 1947, see the editor's postscript and the comment in vol. 5 of

\begin{tabular}{|l|l|l|l|l|}
\hline Revista Dialectus & Ano 9 & n. 18 & Outubro 2020 & p. 39-65 \\
\hline
\end{tabular}


For Adorno, the concept of form - notion, identity, and system - stands for identifying thinking par excellence, which can never do justice to the object and finds its perfect expression in Hegel's philosophy of identity and Beethoven's tonality. Adorno regards the materialism in Negative Dialectics, which opposes the ideological character of reality, with the unwavering insistence on the non-identical, as the implementation of Marx's criticism that Hegel had mystified dialectics with his idealism; Schönberg achieved this in art with his atonal revolution around 1910. Adorno accuses Hegel of identifying thinking, which is as restrictive with the form of the notion as contemporary bourgeois society with its forms of value, i.e., the form of commodity, the form of money, the form of capital, the form of profit, of interest, etc.: 'Nowhere on earth is today's society 'open,' as apologists of scientivism certify it to be; but it is not de-formed anywhere either."75 However, this criticism of Hegel falls behind Marx's and goes past Hegel. ${ }^{76}$ This is because Marx does not criticize the form itself - the forms of the Science of Logic are timeless and would also be valid in a non-capitalist society without being a restriction. Marx criticizes that, contrary to Hegel's thesis, not all oppositions can be mediated in a purely logical manner, i.e., there are logically irreconcilable oppositions and only the forms based on such oppositions should be criticized. ${ }^{77}$ However, this does not - also in value theory - break the form of dialectical presentation altogether, but it is supplemented

Horkheimer's Collected Works (Gesammelte Schriften), pp. 423 ff. and pp. 453 ff., which contains both variants.

75 Theodor W. Adorno: Negative Dialectics, p. 284. ("Nirgendwo auf Erden ist die gegenwärtige Gesellschaft, wie ihr szientifische Apologeten bescheinigen, 'offen;' nirgendwo auch entformt." Theodor W. Adorno: Negative Dialektik. In: AGS, vol. 6, p. 280.)

76 "Zumindest was die Wesenslogik Hegels angeht, scheint Adornos Idealismuskritik offene Türen einzurennen." (Christian Iber: Metaphysik absoluter Relationalität, p. 331, n. 2.)

77 "Actual extremes cannot be mediated with each other precisely because they are actual extremes. But neither are they in need of mediation, because they are opposed in essence. They have nothing in common with one another; they neither need nor complement one another. The one does not carry in its womb the yearning, the need, the anticipation of the other." (Karl Marx: Critique of Hegel's Philosophy of Right) ("Wirkliche Extreme können nicht mit einander vermittelt werden, eben weil sie wirkliche Extreme sind. Aber sie bedürfen auch keiner Vermittelung, denn sie sind entgegengesezten Wesens. Sie haben nichts mit einander gemein, sie verlangen einander nicht, sie ergänzen einander nicht. Das eine hat nicht in seinem eigenen Schoos die Sehnsucht, das Bedürfniß, die Anticipation des andern." - Karl Marx: Zur Kritik der Hegelschen Rechtsphilosophie. In: MEGA $^{2}$ I/2, p. 97, see MEW 1, p. 292.) Marx votes in favor of a dialectic, "the limits of which are to be determined" and which "does not sublate the real difference." ("deren Grenzen zu bestimmen" sind und die den "realen Unterschied nicht aufhebt." - Karl Marx: Einleitung [zu den Grundrissen der Kritik der politischen Ökonomie]. In: MEGA² II/1.1, p. 43, see MEW 13, p. 640.) Accordingly, in this context, it is no longer possible to speak of a unity of setting and presupposing, as in Hegel's case, but instead of a "unity of setting and being presupposed." ("Einheit des Setzens und Vorausgesetztseins" - Andreas Arndt: Unmittelbarkeit, p. 41.) The artistic figuration of the irreconcilable opposition is the grotesque, and its master is Edgar Hilsenrath.

\begin{tabular}{|l|c|c|c|c|}
\hline Q Povista Oialectus & Ano 9 & n. 18 & Outubro 2020 & p. 39-65 \\
\hline
\end{tabular}


by a further logical figure. ${ }^{78}$ Nevertheless, Adorno and Horkheimer's apodictic judgments about the repressiveness of exchanging society remain valid. ${ }^{79}$

However, Marx himself encourages misinterpretations of the concept of form by also using it in meanings that do not synonymously correspond to Hegel's use of the term category, such as the meaning of value as the form of labor ${ }^{80}$ or as the form of exchangeability $^{81}$ (the relation between the values of two commodities, the form of value or exchange-value). The basic category that is addressed in Capital is the notion of value in its forms, which is determined further to the notion of capital, not labor or exchangeability.

Hegel's Science of Logic, explicating the forms of thinking and being, is largely unconditional and thus forms the beginning of the system. According to the current state of research, it essentially has three shortcomings, which, however, do not affect the macro structure of the work as a whole. ${ }^{82}$ First, at the beginning of the Logic, one must explicitly abstract from the real conditions that the transition from logic to nature entails. Secondly, the logic of essence lacks the logical figure of the irreconcilable opposition (i.e., the opposition that cannot be mediated in a purely logical manner) demanded by Marx for a part of these real conditions. Thirdly, and finally, the transition to nature at the end of the Logic, as a consequence of the first shortcoming, is no longer necessary when Hegel speaks of the decision of the idea to "freely discharge itself" 83.84 The very thing that defines the strength of Hegel's philosophy, namely the strict deduction of the categories with the presentation of the inherent requirements, is abandoned here. This is because,

78 For this reason, an abstract separation of form theory from action theory is not possible. Actions are the subject of political economy if, and only if, they have the characteristics of a form.

79 See Theodor W. Adorno: Negative Dialectics, p. 363 and p. 367. (Theodor W. Adorno: Negative Dialektik. In: AGS, vol. 6, p. 356 and p. 359, and Max Horkheimer: Nachtrag. In: HGS, vol. 4, p. 225.)

80 "Political Economy has indeed analysed, however incompletely, value and its magnitude, and has discovered what lies beneath these forms. But it has never once asked the question why labour is represented by the value of its product and labour time by the magnitude of that value." (Karl Marx: Capital. Vol. 1. Part I: Commodities and Money. Chapter 1: Commodities) ("Die politische Oekonomie hat nun zwar, wenn auch unvollkommen, Werth und Werthgröße analysirt und den in diesen Formen versteckten Inhalt entdeckt. Sie hat niemals auch nur die Frage gestellt, warum dieser Inhalt jene Form annimmt, warum sich also die Arbeit im Werth und das Maß der Arbeit durch ihre Zeitdauer in der Werthgröße des Arbeitsprodukts darstellt.” - Karl Marx: Das Kapital. In: MEGA² II/6, pp. 110 f., see MEW 23, pp. 94 f.).

81 "Social form of the commodity and value-form or form of exchangeability are thus one and the same thing." (Karl Marx: Capital (1867). Vol. 1. Chapter 1: The Commodity, translation of the first German edition) ("Gesellschaftliche Form der Waare und Werthform oder Form der Austauschbarkeit sind also eins und dasselbe." - Karl Marx: Das Kapital, Erstausgabe von 1867. In: MEGA² II/5, p. 38.).

82 I would like to thank, in particular, Prof. Andreas Arndt for the important information concerning the Science of Logic.

83 "[S]ich selbst frei" zu entlassen. (G. W. F. Hegel: Wissenschaft der Logik. Die Lehre vom Begriff (1816), p. 305 and Wissenschaft der Logik. In: HTW, vol. 6, p. 573, emphasis as in the original.).

84 This statement from 2009 (German original publication) may not reflect the author's current position.

\begin{tabular}{|l|c|c|c|c|}
\hline Qenista Dialectus & Ano 9 & n. 18 & Outubro 2020 & p. 39-65 \\
\hline
\end{tabular}


under Hegel's assumption of the complete independence of the Logic from real conditions, the logical development ends with the absolute self-referentiality of the pure idea. ${ }^{85}$

Indeed, in the philosophy of nature, Hegel falls back on a mode that is only descriptive, so that his own accusation, originally directed against Kant, of merely taking

\begin{tabular}{|l|l|}
\hline \multicolumn{2}{|c|}{ System } \\
\hline \multirow{2}{*}{ Logic [Hegel's Science of Logic] } & The Doctrine of Being \\
\cline { 2 - 2 } & The Doctrine of Essence \\
\cline { 2 - 2 } & The Doctrine of the Notion \\
\hline \multirow{2}{*}{$\begin{array}{l}\text { Base/Substructure (Nature) [Matter] } \\
\text { [Uno's Principles of Political Economy }]\end{array}$} & The Doctrine of Circulation \\
\cline { 2 - 2 } & The Doctrine of Production \\
\cline { 2 - 2 } & The Doctrine of Distribution \\
\hline \multirow{2}{*}{$\begin{array}{l}\text { Superstructure (Spirit) } \\
\text { [especially Adorno and Horkheimer] }\end{array}$} & Subjective Mind \\
\cline { 2 - 2 } & Objective Mind \\
\cline { 2 - 2 } & Absolute Spirit \\
\hline
\end{tabular}

up the categories externally suddenly applies to him. The treatment of the individual natural sciences is even less satisfactory. As such, their categories are already developed in the Logic, especially that of the natural law. And beyond the realm of Logic, ahistorical categories can no longer be developed at all, as Adorno stated in his critique of any theory of invariants. ${ }^{86}$ The individual empirical results of the natural sciences themselves cannot be the subject of philosophy, and a systematic development of the natural sciences in the philosophy of nature is incompatible with Hegel's program, since its categories were already developed in the sphere of logic and the category of science, as such, belongs to the sphere of spirit.

According to his conception of material philosophy (Realphilosophie), Hegel thematizes, after the logical categories in the Science of Logic, material objects (physical

85 Marx already criticizes this conclusion of the Science of Logic: "To Hegel [...], the process of thinking, which, under the name of 'the Idea,' he even transforms into an independent subject, is the demiurgos of the real world, and the real world is only the external, phenomenal form of 'the Idea." (Karl Marx: Capital. Vol. 1. Afterword to the Second German Edition.) ("Für Hegel ist der Denkproceß, den er sogar unter dem Namen Idee in ein selbstständiges Subjekt verwandelt, der Demiurg des Wirklichen, das nur seine äußere Erscheinung bildet.” - Karl Marx: Das Kapital. In: MEGA² II/6, p. 709, see MEW 23, p. 27.).

86 Even the physical categories of space and time have proven to be not constant, but dependent on their relationship, the speed of light, and this too will one day suffer the same fate in a larger context. According to Marx, with regard to historical time, we are still living in prehistory.

\begin{tabular}{|c|c|c|c|c|}
\hline Qevista Oialectus & Ano 9 & ก. 18 & Outubro 2020 & p. $39-65$ \\
\hline
\end{tabular}


entities, light, etc.) in the philosophy of nature and spiritual objects (psychology, politics, art, religion, and philosophy) in the philosophy of spirit. This corresponds to the logical structure of his system as a unity of immediacy and mediation with, firstly, the immediate relation to itself, secondly, the relationship to others, and, thirdly, the relation to itself through others. But if the categories of the natural sciences are already fully developed in the Logic, then those of material mediation can only be economic, which Hegel considers, contradictory to his regular view, as not explicable. ${ }^{87}$ Marx himself gives us a hint when he says that the "mode of production of material life conditions the social, political and intellectual life process in general" and that on "the economic structure of society, the real foundation," rises "a legal and political superstructure." 88

The reconstruction of an updated system is briefly outlined below in consideration of the historical conditions. The Science of Logic does not require concrete historical conditions, so that under this assumption, the transition to material mediation the economy - can occur, which corresponds to the "pure theory" of capitalism according to Uno. Logically irreconcilable oppositions are already the private property of use values, ${ }^{89}$ as the result of which the exchange principle only emerges, in addition to laborpower as a commodity and the private property of the means of production.

87 "By realizing early on that bourgeois society is based on private property and not on brotherhood and love, a true general (Allgemeines) cannot be established in it through them. He distrusts the bourgeois' ability to make politics, and so the sphere of economics, even up to the Berlin's Philosophy of Right, remains indigestible to the spirit, which in its naturalness cannot be integrated (aufheben), but only subdued. Hegel knows that the real work remains bound to nature and finiteness; for it the opposition to nature applies in all its harshness." ("Indem Hegel früh erkennt, daß die bürgerliche Gesellschaft auf dem Privateigentum und nicht auf Brüderlichkeit und Liebe beruht, ist in ihr und durch sie für ihn ein wahrhaft Allgemeines nicht zu stiften. Er mißtraut der Politikfähigkeit des Bourgeois, und so bleibt auch die Sphäre der Ökonomie bis in die Berliner Rechtsphilosophie ein für den Geist Unverdauliches, das in seiner Naturhaftigkeit nicht aufzuheben, sondern nur zu bezwingen ist. Hegel weiß, daß die wirkliche Arbeit der Natur und Endlichkeit verhaftet bleibt; für sie gilt die Entgegensetzung gegen die Natur in ihrer ganzen Härte." - Andreas Arndt: Zur Herkunft und Funktion des Arbeitsbegriffs in Hegels Geistesphilosophie, p. 113.) Adorno also intends the transition from method to economy. (See HansGeorg Backhaus: Adorno und die metaökonomische Kritik der positivistischen Nationalökonomie, p. 29.).

88 Karl Marx: A Contribution to the Critique of Political Economy. Preface. (Dass die "Produktionsweise des materiellen Lebens" den "socialen, politischen und geistigen Lebensproceß überhaupt" bedinge und sich auf der "ökonomische[n] Struktur der Gesellschaft, d[er] reale[n] Basis," ein "juristischer und politischer Ueberbau" erhebe. - Karl Marx: Zur Kritik der politischen Ökonomie. Erstes Heft. In: MEGA ${ }^{2}$ II/2, p. 100, see MEW 13, pp. 8 f.).

89 "They must therefore, mutually recognise in each other the rights of private proprietors. This juridical relation, which thus expresses itself in a contract, whether such contract be part of a developed legal system or not, is a relation between two wills, and is but the reflex of the real economic relation between the two." (Capital. Vol. 1. Part I: Commodities and Money. Chapter 2: Exchange) ("Sie müssen sich daher wechselseitig als Privateigenthümer anerkennen. Dieß Rechtsverhältniß, dessen Form der Vertrag ist, ob nun legal entwickelt oder nicht, ist ein Willensverhältniß, worin sich das ökonomische Verhältniß wiederspiegelt." - Karl Marx: Das Kapital. In: MEGA² II/6, p. 114, see MEW 23, p. 99.).

\begin{tabular}{|l|l|l|l|l|}
\hline Qevista Dialectus & Ano 9 & n. 18 & Outubro 2020 & p. 39-65 \\
\hline
\end{tabular}


The consequences of the manner of material mediation for spirit and its character are the subject of the superstructure, in which Adorno's actual main work, Aesthetic Theory, with its program of reflecting artistic techniques through the medium of the notion, finds its place. The largest part in the presentation of the superstructure as an integral part of the administrated world is therefore located in the philosophy of Adorno with the category of the culture industry that pre-forms mass consciousness, and then the philosophy of Horkheimer with the category of instrumental reason. The superstructure also includes Uno's stages theory, while the third level - concrete empirical analysis - no longer addresses the categories and is therefore located outside of philosophy. Economic objects are therefore not simply to be found in the base (or substructure), but, depending on their logical nature, also in the superstructure or in empirical analysis outside of philosophy. ${ }^{90}$

History will judge whether the philosophy of reflection ${ }^{91}$ or Hegel's philosophy is the philosophy of freedom - whether freedom is self-determination and arbitrariness, as argued by Kant, or the opposite of external necessity, as put forward by Hegel. ${ }^{92}$

Bibliography

Theodor W. Adorno: Gesammelte Schriften (AGS), 20 vols., Frankfurt/Main 1970 ff.

- Aesthetic Theory, Minneapolis 1997.

- Negative Dialectics, New York 1997.

Hans-Georg Backhaus: On the Dialectics of the Value-Form. In: Thesis Eleven 1 (1980), no. 1, pp. 99-120, doi: $10.1177 / 072551368000100108$.

- Die Irrtümer der nationalökonomischen Marx-Kritik als Grundmängel der nationalökonomischen Theoriebildung. In: Helmut Brentel, Christoph Görg, Fritz Reusswig, Michael Scharping (eds.): Gegensätze. Elemente kritischer Theorie, Frankfurt/Main, New York 1996, pp. 32-47.

- Dialektik der Wertform. Untersuchungen zur Marxschen Ökonomiekritik, Freiburg i. Br. 1997.

- Über die Notwendigkeit einer Ent-Popularisierung des Marxschen "Kapitals." In: Christoph Görg, Roland Roth (eds.): Kein Staat zu machen. Zur Kritik der Sozialwissenschaften, Münster 1998, pp. 349-371.

- $\quad$ Letter to Ken Kubota of December 14, 2000.

- Über den Begriff der Kritik im Marxschen Kapital und in der Kritischen Theorie. In: Joachim Bruhn, Manfred Dahlmann, Clemens Nachtmann (eds.): Kritik der Politik. Johannes Agnoli zum 75. Geburtstag, Freiburg i. Br. 2000, pp. 13-60.

90 The deduction of the form of money is part of the base (or substructure), while the introduction of a currency as an institutional means of circulation belongs to the superstructure.

91 Hegel called a philosophy that stood still at oppositions a "philosophy of reflection."

92 See Max Horkheimer, Theodor W. Adorno: [Diskussion über Theorie und Praxis]. In: HGS, vol. 19, p. 42 and p. 66. Updates to this article will be available online at: https://doi.org/10.4444/100.100.

\begin{tabular}{|l|l|l|l|l|}
\hline Qevista Dialectus & Ano 9 & n. 18 & Outubro 2020 & p. 39-65 \\
\hline
\end{tabular}


- Über den Doppelsinn der Begriffe "Politische Ökonomie" und "Kritik" bei Marx und in der Frankfurter Schule. In: Stefan Dornuf, Reinhard Pitsch (eds.): Wolfgang Harich zum Gedächtnis. Eine Gedenkschrift in zwei Bänden, vol. 2, München 2000, pp. 12-213.

- Über das "Logische” in der Nationalökonomie. In: Das Argument 251 (2003), no. 3, pp. 410-423.

- Adorno und die metaökonomische Kritik der positivistischen Nationalökonomie. In: Andreas Gruschka, Ulrich Oevermann (eds.): Die Lebendigkeit der kritischen Gesellschaftstheorie. Dokumentation der Arbeitstagung aus Anlass des 100. Geburtstages von Theodor W. Adorno, Wetzlar 2004, pp. 27-64.

- Der "fiktive Kommunismus" als die aporetische Grundlage der akademischen Makroökonomie. In: Jens Becker, Heinz Brakemeier (eds.): Vereinigung freier Individuen. Kritik der Tauschgesellschaft und gesellschaftliches Gesamtsubjekt bei Theodor W. Adorno, Hamburg 2004, pp. 60-121.

- Der widersprüchliche und monströse Kern der nationalökonomischen Begriffsbildung. In: Christine Kirchhoff, Lars Meyer, Hanno Pahl, Judith Heckel, Christoph Engemann (eds.): Gesellschaft als Verkehrung. Perspektiven einer neuen Marx-Lektüre, Freiburg i. Br. 2004, pp. 47-82.

Hans-Georg Backhaus, Helmut Reichelt: Der politisch-ideologische Grundcharakter der Marx-Engels-Gesamtausgabe: eine Kritik der Editionsrichtlinien der IMES. In: MEGA-Studien 1994, no. 2, pp. 101-118.

- $\quad$ [Review of:] Karl Marx, Friedrich Engels, Gesamtausgabe (MEGA), hrsg. von der Internationalen Marx-Engels-Stiftung, Zweite Abteilung: "Das Kapital" und Vorarbeiten, Bd. 4.2: Karl Marx, Ökonomische Manuskripte 1863-1867, Teil 2 [...]. In: MEGA-Studien 1994, no. 2, pp. 122-126.

- Wie ist der Wertbegriff in der Ökonomie zu konzipieren? Zu Michael Heinrich: Die Wissenschaft vom Wert. In: Beiträge zur Marx-Engels-Forschung. Neue Folge 1995, pp. 60-94.

Georg Wilhelm Friedrich Hegel: Werke (HTW), Frankfurt/Main: Suhrkamp 1986 ff.

- Wissenschaft der Logik. Das Sein (1812), 2nd ed., Hamburg: Meiner 1999.

- Wissenschaft der Logik. Die Lehre vom Wesen (1813), 2nd ed., Hamburg: Meiner 1999.

- Wissenschaft der Logik. Die Lehre vom Begriff (1816), Hamburg: Meiner 1994.

- Philosophy of Right. Preface, https://www.marxists.org/reference/archive/hegel/works/pr/preface.htm (May 30, 2020), translated by S. W. Dyde, 1896, originally published in German in 1820 as "Grundlinien der Philosophie des Rechts."

- Wissenschaft der Logik. Die Lehre vom Sein (1832), Hamburg: Meiner 1990.

- The Science of Logic. Introduction, https://www.marxists.org/reference/archive/hegel/works/hl/hlintro.htm (May 22, 2020), translated by A. V. Miller, London, New York 1969.

Max Horkheimer: Gesammelte Schriften (HGS), 19 vols., Frankfurt/Main 1985 ff.

Max Horkheimer and Theodor W. Adorno: Dialectic of Enlightenment, translated by John Cumming, London, New York 1997.

Karl Marx: Critique of Hegel's Philosophy of Right, https://www.marxists.org/archive/marx/works/1843/critique-hpr/ch05.htm (May 30, 2020), translated by Annette Jolin and Joseph O'Malley, Cambridge, London 1970.

- A Contribution to the Critique of Political Economy. Preface, https://www.marxists.org/archive/marx/works/1859/critique-pol-economy/prefaceabs.htm (May 31, 2020), translated by S. W. Ryazanskaya, New York 1970.

\begin{tabular}{|l|l|l|l|l|}
\hline Q Povista Dialectus & Ano 9 & n. 18 & Outubro 2020 & p. 39-65 \\
\hline
\end{tabular}


- Capital (1867). Vol. 1. Chapter 1: The Commodity, translation of the first German edition, https://www.marxists.org/archive/marx/works/1867-c1/commodity.htm (May 30, 2020), translated by Albert Dragstedt, London 1976.

- Capital. Vol. 1. Afterword to the Second German Edition, https://www.marxists.org/archive/marx/works/1867-c1/p3.htm (May 31, 2020), translated by Samuel Moore and Edward Aveling, London 1887.

- Capital. Vol. 1. Part I: Commodities and Money. Chapter 1: Commodities, https://www.marxists.org/archive/marx/works/1867-c1/ch01.htm (May 30, 2020), translated by Samuel Moore and Edward Aveling, London 1887.

- Capital. Vol. 1. Part I: Commodities and Money. Chapter 2: Exchange, https://www.marxists.org/archive/marx/works/1867-c1/ch02.htm (May 31, 2020), translated by Samuel Moore and Edward Aveling, London 1887.

Karl Marx, Friedrich Engels: Werke (MEW), 43 vols., Berlin 1956 ff.

- Gesamtausgabe (MEGA²), Berlin 1975 ff.

Helmut Reichelt: Zur logischen Struktur des Kapitalbegriffs bei Karl Marx, Freiburg i. Br. 2001. Originally published in 1970 in Frankfurt/Main and Wien.

- Einige Anmerkungen zu Sybille von Flatows und Freerk Huiskens Aufsatz Zum Problem der Ableitung des bürgerlichen Staates. In: Gesellschaft. Beiträge zur Marxschen Theorie 1 (1974), pp. 12-29.

- Warum hat Marx seine dialektische Methode versteckt? In: Beiträge zur MarxEngels-Forschung. Neue Folge 1996, pp. 73-110.

- Geldmedium und Rechtsform als Konstrukte. Zur kritischen Theorie von Jürgen Habermas. In: Christoph Görg, Roland Roth (eds.): Kein Staat zu machen. Zur Kritik der Sozialwissenschaften, Münster 1998, pp. 372-392.

- Zum Verhältnis von Psychologie und dialektischer Methode in der Marxschen Ökonomiekritik. In: Diethard Behrens (ed.): Geschichtsphilosophie oder das Begreifen der Historizität, Freiburg i. Br. 1999, pp. 79-126.

- Grenzen der dialektischen Darstellungsform - oder Verabschiedung der Dialektik? Einige Anmerkungen zur These von Dieter Riedel. In: MEGA-Studien 2000, no. 1, pp. 100-126.

- Die Marxsche Kritik ökonomischer Kategorien. Überlegungen zum Problem der Geltung in der dialektischen Darstellungsmethode im "Kapital." In: Iring Fetscher, Alfred Schmidt (eds.): Emanzipation als Versöhnung. Zu Adornos Kritik der "Warentausch"-Gesellschaft und Perspektiven der Transformation, Frankfurt/Main 2002, pp. 142-189.

- Marx's Critique of Economic Categories: Reflections on the Problem of Validity in the Dialectical Method of Presentation in Capital. In: Historical Materialism (2007), vol. 15, no. 4, pp. 3-52, doi: 10.1163/156920607X245823; English translation of "Die Marxsche Kritik ökonomischer Kategorien. Überlegungen zum Problem der Geltung in der dialektischen Darstellungsmethode im 'Kapital'."

- Zum Problem der dialektischen Darstellung ökonomischer Kategorien im Rohentwurf des Kapitals. In: Beiträge zur Marx-Engels-Forschung. Neue Folge 2007, pp. 87-103.

- $\quad$ Neue Marx-Lektüre. Zur Kritik sozialwissenschaftlicher Logik, Hamburg 2008.

Isaak Iljitsch Rubin: Studien zur Marxschen Werttheorie, Frankfurt/Main 1973. After the (then unpublished) English translation of the third Russian edition of Очерки по теории стоимости Маркса, Moscow and Leningrad 1928, translated by Annette Neusüss-Fögen, originally published in Russian in 1923.

\begin{tabular}{|l|l|l|l|l|}
\hline Qevista Dialectus & Ano 9 & n. 18 & Outubro 2020 & p. 39-65 \\
\hline
\end{tabular}


Isaak Illich Rubin: Essays on Marx's Theory of Value, 4th printing, Montréal, New York 1990, originally published in 1973, translated by Miloš Samardźija and Fredy Perlman from the third (Russian) edition, Moscow and Leningrad 1928.

I[saak] I[1jitsch] Rubin, S. A. Bessonow et al.: Dialektik der Kategorien. Debatte in der UdSSR (1927-29), Berlin (West) 1975.

Thomas T. Sekine: Uno-Riron: A Japanese Contribution to Marxian Political Economy. In: Journal of Economic Literature 13 (1975), pp. 847-877, doi: 10.4444/34.100.

- The Dialectic of Capital. A Study of the Inner Logic of Capitalism, 2 vols., Tokyo 1986, doi: $10.4444 / 34.1$.

- $\quad$ An Outline of the Dialectic of Capital, 2 vols., London, New York 1997.

Kozo Uno: Principles of Political Economy. Theory of a Purely Capitalist Society, Brighton, Atlantic Highlands, New Jersey 1980, translated by Thomas T. Sekine, originally published in Japanese in 1964 as "Keizai Genron."

Further Literature

Andreas Arndt: Karl Marx. Versuch über den Zusammenhang seiner Theorie, Bochum 1985.

- Zur Herkunft und Funktion des Arbeitsbegriffs in Hegels Geistesphilosophie. In: Archiv für Begriffsgeschichte 29 (1985), pp. 99-115.

- Unmittelbarkeit, Bielefeld 2004, doi: 10.4444/50.10.de.

John R. Bell: Capitalism and the Dialectic. The Uno-Sekine Approach to Marxian Political Economy, New York 2009.

Helmut Brentel: Soziale Form und ökonomisches Objekt. Studien zum Gegenstands- und Methodenverständnis der Kritik der politischen Ökonomie, Opladen 1989.

Albert Einstein: Why Socialism? In: Monthly Review. An Independent Socialist Magazine 1 (1949), no. 1, pp. 9-15.

Georg Fülberth: G Strich. Kleine Geschichte des Kapitalismus, 4th ed., Cologne 2008.

Setsuo Furihata: Entwicklung des japanischen Kapitalismus und marxistische Wirtschaftswissenschaft in Japan. In: Prokla. Zeitschrift für politische Ökonomie und sozialistische Politik 66 (1987), pp. 76-90.

Gerhard Göhler: Die Reduktion der Dialektik durch Marx. Strukturveränderungen der dialektischen Entwicklung in der Kritik der politischen Ökonomie, Stuttgart 1980.

Klaus Hartmann: Die Marxsche Theorie. Eine philosophische Untersuchung zu den Hauptschriften, Berlin (West) 1970.

Michael Heinrich: Die Wissenschaft vom Wert. Die Marxsche Kritik der politischen Ökonomie zwischen wissenschaftlicher Revolution und klassischer Tradition, 2nd ed., Münster 1999.

- Kommentierte Literaturliste zur Kritik der politischen Ökonomie. In: Elmar Altvater, Rolf Hecker, Michael Heinrich, Petra Schaper-Rinkel: Kapital.doc. Das Kapital (Bd. 1) von Marx in Schaubildern mit Kommentaren, Münster 1999, pp. 188-220.

Jan Hoff: Kritik der klassischen politischen Ökonomie. Zur Rezeption der werttheoretischen Ansätze ökonomischer Klassiker durch Karl Marx, Cologne 2004.

- Karl Marx und die "ricardianischen Sozialisten." Ein Beitrag zur Geschichte der politischen Ökonomie, der Sozialphilosophie und des Sozialismus, Cologne 2008.

- Marx global. Zur Entwicklung des internationalen Marx-Diskurses seit 1965, Berlin 2009, doi: 10.4444/110.1.de.

- Marx Worldwide. On the Development of the International Discourse on Marx since 1965, Leiden, Boston 2017, doi: 10.4444/110.1, English translation of "Marx global. Zur Entwicklung des internationalen Marx-Diskurses seit 1965."

\begin{tabular}{|l|l|l|l|l|}
\hline Qenista Dialectus & Ano 9 & n. 18 & Outubro 2020 & p. 39-65 \\
\hline
\end{tabular}


Jan Hoff, Alexis Petrioli, Ingo Stützle, Frieder Otto Wolf (eds.): Das Kapital neu lesen. Beiträge zur radikalen Philosophie, Münster 2006.

Christian Iber: Metaphysik absoluter Relationalität. Eine Studie zu den beiden ersten Kapiteln von Hegels Wesenslogik, Berlin, New York 1990.

- Grundzüge der Marx'schen Kapitalismustheorie, Berlin 2005.

Hyeon-soo Joe: Politische Ökonomie als Gesellschaftstheorie. Studien zur Marx-Rezeption von Isaak Iljitsch Rubin und Kozo Uno, Diss. Philipps-Universität Marburg 1995.

Ken Kubota: Die dialektische Darstellung des allgemeinen Begriffs des Kapitals im Lichte der Philosophie Hegels. Zur logischen Analyse der politischen Ökonomie unter besonderer Berücksichtigung Adornos und der Forschungsergebnisse von Rubin, Backhaus, Reichelt, Uno und Sekine. In: Beiträge zur Marx-Engels-Forschung. Neue Folge 2009, pp. 199-224, doi: 10.4444/100.100.de.

- Philosophical Bibliography, Berlin 2019, doi: 10.4444/100.110.

Shohken Mawatari: The Uno School: a Marxian approach in Japan. In: History of Political Economy 17 (1985), no. 3, pp. 403-418.

Kiyoshi Nagatani: Fallacy of Rubin's Value Theory: a Critique from the Perspective of Uno's Method, unpublished manuscript of a lecture given at the 2005 annual conference of the Japanese Society for Political Economy.

Projektgruppe zur Kritik der politischen Ökonomie [Charlotte Deworsack, Philine Deworsack, Frank Flegel, Joachim Heidorn, Michael Mittmann]: Zur Logik des Kapitals, 2nd ed., Berlin (West) 1973.

Ljudmilla Vasina: I. I. Rubin - Marxforscher und Politökonom. In: Beiträge zur MarxEngels-Forschung. Neue Folge 1994, pp. 144-149.

Michael Wolff: Der Begriff des Widerspruchs. Eine Studie zur Dialektik Kants und Hegels, Königstein/Ts. 1981.

- Realitätsstufen oder Entwicklung? Hegels „Realphilosophie“ und die Philosophie der Wissenschaften. In: Hegel-Jahrbuch 1989, pp. 397-413.

\begin{tabular}{|l|l|l|l|l|}
\hline Qevista Qialectus & Ano 9 & n. 18 & Outubro 2020 & p. 39-65 \\
\hline
\end{tabular}

